\title{
Do Loyalty Program in the Airline and Hotel Industries Affect Customer Satisfaction and
} Loyalty?

Eslam Ahmed Fathy Fathy ${ }^{1} \quad$ Heba Abdel Karim Youssef Zidan ${ }^{2}$

${ }^{1}$ Faculty of Tourism and Hotel Management Pharos University- Alexandria

${ }^{2}$ High institute of tourism, Hotel Management and Monuments Restoration, Abou Qir-Alexandria

\begin{abstract}
This paper offers a framework for studying the frequent loyalty programs' role in flyers'/guests' satisfaction and loyalty throughout a hospitality and airlines industries. The purpose of the study aims to examine the effect of loyalty programs on enhancing flyers'/guests' satisfaction and loyalty and the mediation role of satisfaction between the relationship between frequent loyalty program and loyalty in the context of airlines and hospitality industry. The survey used a threesection format, first section asking the respondents about the frequent loyalty program in hotel, second section asking them about frequent loyalty programs in airlines, and finally, ask about respondents' profile. 276 questionnaires were collected from twice tourist's frequent membership in loyalty programs (airlines/hotels). This study obtained secondary data from Alexandria hotels and performed the Correlation and regression and mediation models to test the study hypotheses. The results analyzed to draw general conclusions regarding the effect of the frequent loyalty programs on flyers'/guests' satisfaction and loyalty. Results of this study supported the research hypotheses and indicated firstly, that loyalty programs do have positive significant effects on flyers'/guests' satisfaction and loyalty. Secondly, the airlines' frequent loyalty programs have effects more than hotel frequent loyalty programs. Thirdly, the satisfaction significant mediates the relationship between the frequent loyalty program and loyalty. The findings are expected to provide valuable insights for hotel marketers to understand the gap in frequent hotel loyalty programs and develop marketing tactics, improve hotels' frequent loyalty programs to maintain loyal guests and maximize profitability as well.
\end{abstract}

Key Words: Flyers, guests, frequent loyalty program, flyers'/guests' satisfaction, flyers'/guests' loyalty, effects, affect, correlation, regression, and mediation.

\section{Introduction}

In the hyperactive, highly, and saturated competitive industries, such as hospitality, tourism, and airlines. They are constantly working not only to win customers, but work enthusiastically to find new methods of establishing and maintaining customer loyalty in order to achieve revenue, finally to succeed which is a clear challenge. Thus, the loyal customers are extremely valuable, because they are considered as a marketing tool that may attract some new potential customers within the positive word -of -mouth without any efforts or costs spent by the businesses, they tend to spend more money than non-loyal customers and have emotional connections, and are less likely to purchase the rival business's products and service based on price alone (Bowen and Shoemaker, 2003). Dowling and Uncles (1997) and Wansink (2003) also added that the cost of acquiring a new customer by enticing means such as low price, discounts, and other marketing activities is higher six times in cost of maintaining current customer. In other word due to decreasing marketing activities cost, increasing the profits, seeking to provide more convenient rewards (Hantuli, 2016). The loyalty (frequent flyers/guests) programs aim to achieve a customer satisfaction and value in order to maintain profitable customers' segments (Bolton, Kannan, and Bramlett, 2000). 
However, there are published researches that investigated the impacts of loyalty (frequent flyers/guests) programs on the customer in airlines and hotel industries separately in Alexandria, but no previously published researches compared between the loyalty (frequent flyers/guests) programs effects on customers' satisfaction and loyalty between the mentioned industries in Alexandria, leaving a gap in the literature body. This study contributes to extant the literature. This research aims at assessing the impacts of loyalty program on customers' satisfaction and loyalty through three objectives. Firstly, investigating the relationship between loyalty (frequent flyers/guests) programs of hospitality and airlines industries; customer satisfaction and customer loyalty. Secondly, illustrating that customer perceived loyalty (frequent flyers/guests) programs have independent effects on customer satisfaction and substantively distinctive effects on customer loyalty. Thirdly, improving the effectiveness of loyalty (frequent flyers/guests) programs in order to eliminate the weakness features of loyalty program.

\section{Literature Review \\ Customer satisfaction}

The competitive advantage of the company is realized when the ability to deliver high service quality results in satisfied customer. (Shemwell et al. 1998).Muffato and Panizzolo viewed that customer satisfaction is one of the most important competitive factors of the company's future, which drives a company to improve its reputation and image to reduce customer turnover and to increase attention to customer needs ( Kandampully and Suhartanto 2000). Shin and Elliott (2001) concluded that, through satisfying customers, companies could improve profitability by expanding their business and gaining a higher market share as well as repeat business (Clemes and Gain et. al, 2008) Hansemark and Albinsson, (2004) mentioned that satisfied customers are willing to purchase additional products and to pay more for the benefits they receive and are more likely to be tolerant of an increase in price and less influenced by competitors (Baker, 2013). Marketing literature is considering that satisfaction is a necessary antecedent to customer loyalty (Sivadas and Baker-Prewitt, 2000; Abdullah and al., 2012, Grandpierre, 2015).

\section{Customer Loyalty}

According to Kotler, et al. (1999) who defined customer loyalty as customer intention behaviors to purchase the same products and service and willing to spend more on other service and facilities for the same property, refer the property to others. Similarly, the Oliver (1999) defined customer loyalty as emotional attachment, which motivates them to repurchasing consistently in the future. Moreover, other researchers such as Petrick, (2004) concludes the customer loyalty in two dimensions, behavioral (the intention of repeat purchase) and favorable attitude towards the service provider (the emotional commitment). He adds that the repeat customer is not only providing a financial benefit to property, but he is also considered as information channel, and referral channel to their friends, families, and potential customers. According to Lee and Cunninghan (2001) customer loyalty is a tendency to be a customer of current suppliers depending on their previous experiences and expectations for the future (Bishop,2013).

Customer loyalty is a win-win situation, as business benefits from decreased marketing cost to acquire new customers that leads to more profits, less price sensitivity, and positive word of mouth, while customers benefit in the situation of discounts or other rewards, simplifying the customers' experience, and familiar of service and product interactions. Customer loyalty is being considered as a valuable gain in the competitive world (Hantuli, 2016). 


\section{The Loyalty Program}

The loyalty program is known as frequency programs and rewards or points programs, which is developed to raise customer loyalty. Loyalty program is defined as "any incentive system that attempts to enhance consumers' consumption behavior over time"(Palmatier and Steinhoff, 2014). Firstly, the airline industry is pioneer of developing the Frequency programs (frequent Flyer Programs) by offering free flights to passengers based on their accumulated travel miles by American airline 1981.

After the success of airlines loyalty programs (Frequent Flyer program), most hospitality chains inspired the idea, and have developed the Frequent Guest Program, which aims to create a relationship with guests, attract new ones, retain their current guest (Xie and Chen, 2013).Hotels reward the guests with free nights based on their number of nights occupied. Dekay, et al (2009) surveyed 287 hotel guests, they stated that $81 \%$ of sample are joined to frequent flyers programs, while $62 \%$ of them are joined to hospitality frequent guest programs. They also noted that the airline industry has more members in Frequent Flyer program than the members in frequent guest programs of hospitality industry. They also argued that airlines award programs have features such as the ease of redemption, strong appeal, and the partnership network that influence its popularity, and become more attractive than hospitality point award programs. Yan and Cui (2016) found that the number of partners and the number of redemption options positively affect the popularity of the loyalty program.

\section{Types of loyalty programs}

1. Rewards: Points can be exchanged for rewards. This type is used when a company wants to gain new customers and be more competitive.

2. Rebate: Awards a gift coupon redeemable for the next purchase, when the customer reaches some shopping levels.

3. Appreciation: offers a rebate.

4. Partnership: Rewards the consumer's accumulated purchases with a partner's service.

5. Affinity: offers special communications, value added benefits and bonuses (Hikkerova, 2014).

Butscher (2002) stated that the effective customer loyalty programs don't depend on only the financial incentives such as discount, because it can't create loyalty relationship, customers switch to other business if they find a better price elsewhere. The well-designed loyalty program should be built on trust, emotion, and partnership for long-term customer loyalty. Recognizing the factors that customers/ guests consider within loyalty programs, makes it easier for marketers to establish more appealing features in the program (Hantuli, 2016).

Implementation of (frequent flyers /guests) programs help airlines and hotels to retain their most profitable customers, promote loyalty towards them, and then they aim to lengthen the entire period spend by the customer and to strengthen the airline's /hotel's position (Oracle, 2008; Dolnicar et al., 2011, Douglas and Mclachlan, 2016).

As a result, loyalty (frequent flyers/guests) programs are considered as a critical component to maintain competitive parity within the hospitality and airlines industries.

\section{Loyalty (frequent flyers/guests) programs and Customer satisfaction}

The satisfied customers are more profitable segment, due to being loyal customer, if they gain the promised value (O'Brien and Jones, 1995).Also Broekhuizen and Peelen, (1997) noted that loyalty programs are designed to increase customer's satisfaction and commitment towards the service providers. Also, Keh and Lee (2006) assured Broekhuizen and Peelen results by measuring the effectiveness and appropriateness of customer loyalty programs to achieve levels 
of customer satisfaction. Zakaria et al. (2014) conducted a study to assess the relationship between loyalty programs and customer satisfaction, and the they found that participants in loyalty programs have more satisfaction, positive behavior, trust and commitment towards than non-participant, and the Zakaria et al. finding confirmed the Gomez, Arranz and Cillan (2006) findings which indicated that the loyalty programs and customer satisfaction are positively and significantly correlated. . Accordingly, we formulate the following research hypothesis:

H1a: The loyalty programs (Frequent Flyers' Programs) affect airline flyers' satisfaction.

H2b: The loyalty programs (Frequent Guests' Programs) affect hotel guests' satisfaction.

\section{Loyalty (frequent flyers/guests) programs and Customer loyalty}

The guest may be holding many loyalty programs. Thus, the hospitality business should develop an active loyalty programs, which are vital and ingenious marketing tools in attracting the guests to repurchase and increase the hotel profitability if are wisely operated (Yoo, 2005;Clark, 2014). Yoo (2011) stated that hotel loyalty (frequent flyers/guests) programs have a positive impact on customers' behavioral loyalty and hotel profitability, because the loyalty (frequent flyers/guests) programs encourage them to repurchase or increase the purchase amountThe Anuar research team (2013) stated that every hotel is constantly trying to design loyalty (frequent flyers/guests) programs that are different from competitors to gain customer loyalty. The airlines and hospitality business are looking for customers' loyalty, because the true loyal customer isn't easily affected even if his/her last experience was unsatisfactory, and may repurchase the business's services and products. In airlines industry, Chin's study (2002) included 192 members of the FFP in Singapore, has presented that FFP is important when making decision about an airline company, Whyte (2003) conducted a study including 171 members of the FFPs, $62 \%$ of the participants stated that the FFP increased their loyalty to the company. Artuger and Calakoglu (2013) found that FFPs have significant effect on customer loyalty.

\section{Factors that affect preferences of customer loyalty programs}

Brien and Jones (1995) and Mayer, Benavent (2005) determine four elements:

1. The ease in using the program: (Program easiness): the easier to implement the loyalty program, the higher the rate of success is. The most important point is that the staffs working for public relations and for information lines have to be well-informed and trained on the program in order to inform the airline passengers and the hotels' guest.

2. The monetary value of the rewards: From the consumer's side, the loyalty program becomes more interesting when the value ratio of the reward increases.

3 . The variety of the rewards: Krstgens (1995) noted that $25 \%$ to $35 \%$ of the loyalty programs offer special events. There are various types of rewarding offered in loyalty programs such as gift checks, free tickets, tickets at a reduced price and extra miles used in the frequent flyer programs.

4. Aspired value for the rewards: a non-monetary reward of equal value has a more perceived value. Thus, a price reduction is easily used by competitors, from the customer's point of view. A free flight to an exotic destination has more perceived value than a pure monitory reward.

5. Probability of getting (reaching) the reward: (By delaying reward or immediate reward) the immediate rewards are price reductions directly deduced on certain producer brands in promotion. The delay rewards increase long-term loyalty and the customer's "locking".

Actually, hotels, airlines, restaurants and retailers offer many types of incentives to customers to enhance loyalty (Mccall and Voorhees, 2010). Loyalty programs create beneficial impacts on 
customers and companies. The programs reward loyal customers, produce important informative data related to customers, control customer behavior, and protect from competition (Berezan, Raab, Tanford, \& Kim, 2013; O’Malley, 1998). Loyalty programs build "barriers to exit" or "switching barriers/costs" which make it difficult to switch to competitors (Bansal, Irving, \& Taylor, 2004; Fornell, 1992; Nunes \& Dréze, 2006, Tanford, Raab, \& Kim, 2011). Active loyalty creates loyal customers who are even willing to pay a premium price because they value their relationships with companies (Backhaus et al. 2012; Keh \& Lee, 2006; Zeithaml, Berry, \& Parasuraman, 1996; Choi, 2015)

The effectiveness and the relevancy of loyalty program are measured through the achievement of certain levels of customer's satisfaction threshold (Keh and Lee, 2006). Accordingly, we formulate the following research hypothesis:

H2a: The loyalty programs (Frequent Flyer's Programs) affect airline flyers' loyalty.

H2b: The loyalty programs (Frequent Guests' Programs) affect hotel guests' loyalty.

\section{The Loyalty Program Effects}

1. Reduces marketing cost. Airlines and hospitality operations assign cost to entice new customers to purchase their products, such as advertising.

2. Increases profits: the repeat customers assure the growth and profit.

3. Increases the customer familiarity and reduces operating cost: the repeat customers in hotels will be familiar to hotel facilities and services, thus their spending average will increase in the same hotels or other hotels of the same chain, because they are encouraged to purchase more/other products and services. The loyal customers will be less depending on hotels/airlines staff. On the other hand, they are easier to serve than No-loyal - customer and are more profitable segment.

4. Increases positive Word- of- Mouth: loyal customer recommends the business to friends and others. Also, they are considered a vital tool in attracting new customers.

5. Less sensitive to a price: the loyal customer can continue to purchase the products and services, even if the price is higher than competitors (Grandpierre, 2015).

Tepeci, Mustafa (1999) stated that repeat business represented a large percentage of hospitality revenue by maintaining high level of occupancy. (Mayer-Waarden, 2008) concluded that Loyalty programs are vital defensive marketing tools in the hospitality industry to maintain existing guests. They create a feeling of belonging and make customer feel important. Moreover, loyalty programs tend to create a sense of community and personal recognition (Grandpierre, 2015).

\section{Characteristics of best loyalty program}

Airlines make traveler's experience different by allowing them early boarding and the opportunity to easily stow carry-on bags. Many airlines provide special lounges typically for those in the top tier away from airport crowds, providing amenities and comfort which make the customer feel special. Consider International Hotels such as, Hilton, Hyatt and Sofitel, all offers services and rooms in effectively comparable standard by making customer's experience different and allow them to choose reward nights without any blackout dates (Tanford, 2013; Douglas and Mclachlan, 2016). 
Figure 1: Characteristics of good loyalty programs

\begin{tabular}{|c|c|c|c|c|c|c|c|}
\hline \multicolumn{7}{|c|}{ Characteristics of good loyalty programs } \\
\hline $\begin{array}{c}\text { Frequently } \\
\text { purchase }\end{array}$ & $\begin{array}{c}\text { Variety of } \\
\text { choices } \\
\text { between } \\
\text { providers }\end{array}$ & $\begin{array}{c}\text { Multiple tiers } \\
\text { of customers }\end{array}$ & $\begin{array}{c}\text { Expiration } \\
\text { of missed } \\
\text { point }\end{array}$ & $\begin{array}{c}\text { Different } \\
\text { customers } \\
\text { experience in } \\
\text { the top tiers }\end{array}$ \\
\hline
\end{tabular}

Source: The research team.

\section{Customer satisfaction and customer loyalty}

Amin, Leila, and Zahra (2014), Zakaria et al. (2014) stated that customer satisfaction is positively and significantly correlated with customer loyalty. Similarly, Pi and Huang (2011), conducted a study a in CKS airport in Taiwan, it showed that passenger satisfaction has positive impacts on the passenger loyalty. Past studies have shown that customer satisfaction tends to lead to customer loyalty (Bose and Rao, 2011). A customer will stay loyal if he perceives that the company gives him better product or services than competitors (Grand Pierre, 2015). Satisfaction thus has a positive and significant impact on customer loyalty and word of mouth intentions (Khan, 2012; Spreng, Harrell, and Mackoy, 1995; Shrestha, 2015). Also, Suhartanto, (2000) stated that the customer satisfaction was tested as a prerequisite for guest loyalty in many researches. He also clarified the significance of guests' satisfaction to encourage the guest to repurchase, to referral the hotels' products and services to relatives and friends. Gronholdt, Martensen, and Kristensen (2000) determined that there is a significant link between customers' satisfaction and loyalty. Thus, satisfaction positively affects the intention of customers to purchase repeatedly. (Jasinskas, et.al, 2016). Jay and kandompully (2016) noted that customer satisfaction is an important outcome of marketing activities in tourism industry, to expand the business, to gain a higher market share and to acquire repeat business, which lead to improving profitability (Barsky, 1992). The study conducted by Cronion and Taylor (1992) in service sectors found that customer satisfaction has a significant effect on purchase intentions. Gretty and Thompson (1994) studied the relationship between quality of lodging, satisfaction, and effects on customer intentions to recommended the lodging operations to prospective customers who mean that there is a positive relationship between customer satisfaction and customer loyalty. According to Heskett, Jones, Loveman, Sasser, Jr., and Schlesinger (1994), loyalty is a direct result of customer satisfaction. According to Oliver (1999) customers at the affective stage would develop a positive attitude towards the brand as a result of satisfactory repetitive usage over time. Customer satisfaction is related to customer's expectations which are met by a given operation. However, customer loyalty is related to the possibility to be a repeat customer to repurchase. Without loyalty, we can have satisfaction. However, without satisfaction, it is difficult to have loyalty (Chitt et al., 2007, Choi 2015, Shrestha, 2015). Hence, Previous research (Cronin and Taylor, 1992; Fornell, 1992 has demonstrated that satisfaction is strongly associated with re-purchase intentions (Baker, 2013). The most accepted view is that satisfaction has a positive impact on loyalty (Sivadas and Baker-Prewitt, 2000; Abdullah and al., 2012, GrandPierre, 2015)

Thus, means improving guest loyalty, which becomes the vital tool for business's long -term success. Thus, the hotels' business must strive strongly to develop and increase the guest loyalty, because it has effects on guests' retention, repurchase, and positive word-of-Mouth, due to market growth and expansion (Laškarin, 2013). 
It is worth to mention that the satisfied guest is not enough to attain its loyalty, but by also going the extra miles and delighting and dazzling them, because many hotels deliver the basic expectations, thus the hotel should offer loyalty programs that exceed the basic expectations to maintain repeated guest. In other words, in fierce competitive marketplaces such as airline and hospitality industries, which the customer/guest have many choices, satisfaction is not significantly correlated to loyalty as proved by Ouhna and Mekkaoui (2013). Also Reichheld (2006) criticizes the use of customers' satisfaction research to determine customers' loyalty and suggested that to measure loyalty by questioning, customers should only be asked: 'Would you recommend us to your friends?' which we use in our questionnaire (Jasinskas, 2016) Accordingly, we formulate the following research hypothesis:

H3a: The flyers' satisfaction affects flyers' loyalty.

H3b: The guest's satisfaction affects guests' loyalty.

Lam, Shanker, Erramilli, and Murthy (2004) also claimed that customer satisfaction indirectly influences loyalty or mediates the relationship between satisfaction-loyalty program, as one of the potential antecedents in developing customer loyalty. They also indicated that satisfaction has positive impacts on some indirection behavior of customers' loyalty such as repurchasing form the same provider and recommending the suppliers to others. Accordingly, we formulate the following research hypothesis:

H4a: The flyers' satisfaction will mediate the relationship between the frequent flyers' loyalty program and flyers' loyalty.

H4b: The guests' satisfaction will mediate the relationship between the frequent guest' loyalty program and guests' loyalty.

\section{The proposed theoretical model}

Figure 2: The proposed theoretical model

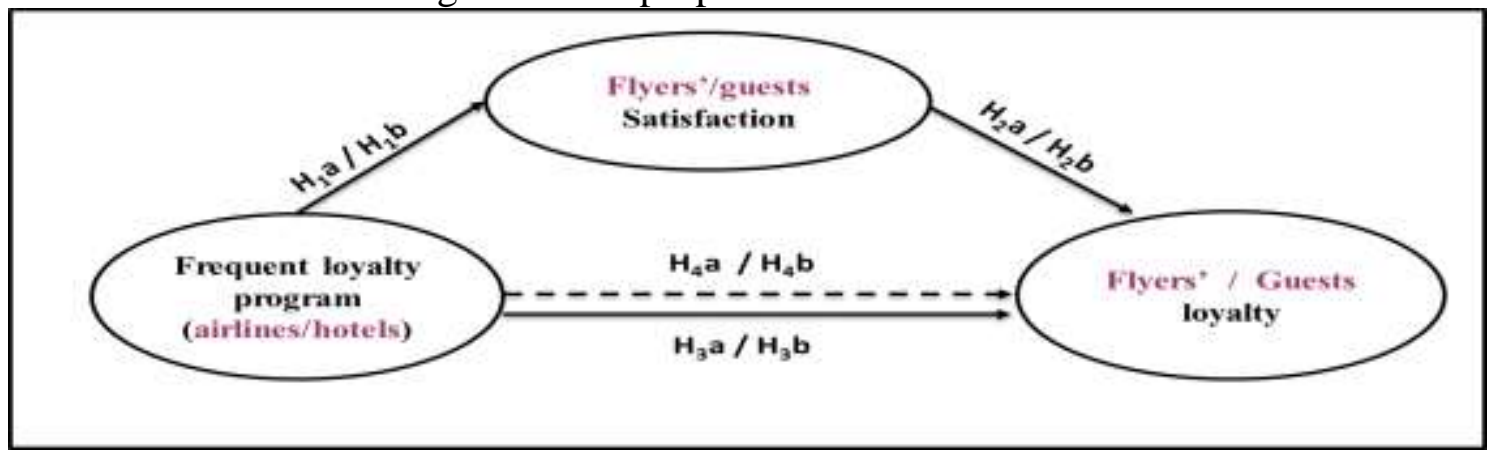

Source: The research Team.

\section{Methodology}

The impact of loyalty program on flyers'/guests' satisfaction and loyalty in airlines and hotels industries is determined in this research. Impact means loyalty programs achieved have an effect on enhancing customer satisfaction and repurchase behavior attached to loyalty to the company; and vice versa. There for, an empirical study test the hypotheses proposed and a quantitative research approach, based on the distribution of questionnaires, was applied within this study. Questionnaire is answered between the first of December and the first of January 2016/2017, by flyers/guests members of loyalty program in five star hotels chain in Alexandria (Sheraton, Hilton, etc ...) who present important popular loyalty program. The reason why we choose Loyalty (frequent flyers/guests) programs members in hotels and airlines firstly is to investigate 
their answers to know which of programs is popular, and more effective on customer satisfaction and loyalty in tourism industry. Secondly, it is believed that there is a knowledge gap in the field of study.

The total population of this research included flyers'/guests' members in both loyalty programs (Hotels' and airline' frequent loyalty program). Hence, it was difficult to use random sampling techniques because of the greatest number of participants. The sample size of search is considered large and not known size. The sample size is infinite about 374 (Bartllet et al.,2011), thus, the researcher distributed 400 questionnaires, then 318 were returned and valid questionnaires was used to conduct the data analysis were 276, giving a response rate of $69 \%$.

\section{Collection of research data and questionnaire development}

To collect data, questionnaires were distributed to guests of five different chain hotels in Alexandria. The reception desks in hotels were responsible to deliver questionnaires to those guests' / flyers members checking or traveling during the period of data collection.

Questionnaires were sent to 20 individuals to pre- test and made comments regarding the readability and flow of questions. We consulted some specialists about the understanding and clearness of questions. A calculation of Cronbach alpha is made and all the calculated Cronbach alpha were greater than 0.70

In this study questionnaires consisted from three sections applied on hotels and airlines loyalty programs. Some variables are used for examination such as flyers'/guests' satisfaction, flyers'/guests' loyalty, and impact of hotels and airlines/hotel' frequents loyalty programs, which were measured by using likert type scales $1=$ strongly disagree, $2=$ disagree, $3=$ neutral, $4=$ agree, $5=$ strongly agree.

The first section consisted of 5 statements, and aimed at measuring guests satisfaction (statement 1-5), guests loyalty (statement 6-11,17-18) and impact of loyalty programs in hotel industry (statement 12-16). The second section consisted of 18 statements, and aimed at measuring flyers' satisfaction (statement 19-23), flyers' loyalty (statement 24- 29, 35-36) and impact of loyalty programs in airline industry (statement $30-34$ )

The third section consisted of 13 questions. The first part of this section consisted of 8 questions and aimed at collecting demographic data of participants' members in loyalty program and their behavior characteristics (age, gender, marital status, education, income, purpose of travel, times of staying/flying).

\section{Obstacles / barriers of research}

Although there is a worldwide trend towards rewards programs, the research team found many barriers especially in distributing questionnaire and collected responses in 5 star hotels and airlines in Alexandria. Internationally, most studies, particularly those done online as a survey, including rewards programs, experience a low response rate (Lubbe, Douglas and Mclachlan, 2016). These barriers relates to the refuse of many (5 star) hotels (for the distribution of our questionnaire pretending it is against policy.

\section{Results and Discussion \\ Reliability and Validity}

Table (1) illustrates reliability statistics for all study variables. 
International Journal of Heritage, Tourism and Hospitality Vol. (11), No. (3/2)

Special issue on papers of the $10^{\text {th }}$ ICTH (2017) organized by Faculty of Tourism and Hotels, Fayoum University

Table 1: Reliability and Validity Statistics for All Study Variables

\begin{tabular}{|l|c|c|}
\hline \multicolumn{1}{|c|}{ Study variables } & Cronbach's Alpha & Validity \\
\hline Guests' satisfaction & .853 & 0.923 \\
\hline Guests' loyalty & .866 & 0.930 \\
\hline Frequent Guest loyalty program & .816 & 0.903 \\
\hline Flyers' satisfaction & .914 & 0.956 \\
\hline Flyers' loyalty & .896 & 0.946 \\
\hline Frequent Flyers' loyalty program & .939 & 0.969 \\
\hline
\end{tabular}

Cronbach's alpha was applied to measure reliability which ranged from 0.816 to 0.939 . The reliability alpha for all studied items indicated a satisfactory level, as they were well above the cut point 0.70 , recommended by Nunnally (1978). On the other hand, the root square of cronbach's alpha was applied to measure the validity of all study variables which ranged from 0.934 to 0.960 . These results mean that the correlation between the factors and the variables were high and the validity was supported which the results were more than $60 \%$ as a minimum acceptable target.

Table (2) Table shows that the measurement statements for frequent flyers' program in airlines industry Are based on three factors namely (psychological treatment) (program benefits) (reasonable cost). More than $46 \%$ of respondents agree to expect a better and quicker service as a loyalty member in Airline program loyalty. In addition they recorded the highest (mean $=3.79$ ) and also they feel special if they were member of airline loyalty program.

Due to the table (3) it can be observed that flyers' satisfaction toward airline is above the average level, it is very clear in the statement (I truly enjoyed staying at airline (mean $=3.87$ ). we noted that $56.6 \%$ of respondents agree that they are satisfied when they choose airline, and almost 54\% reach the second ranking when we asked about the moderation between experience with Airline services and expectation. Additional statements measuring flyers' satisfaction in comparison to the airline's competitors and in level of receiving services (with mean $=3.81 / 3.72$ ).

As can be seen in table (4) flyers' loyalty toward airline is above the average level which the statement (I recommend Airline to others) present the highest level of (mean $=3.75$ ) $50.9 \%$ of respondents agree to recommend Airline to others. In addition $49.1 \%$ of respondents agree to say positive things about airline to others. We notice that all other statements included measure the flyers' overall loyalty towards the airline with mean varied between (3.73 and 3.69).

In the table (5) there are findings about the participation in Program loyalty, from the given data, it is possible to see that, the hospitality business should develop an active loyalty programs, which are vital and ingenious marketing tools in attracting the guests to repurchase and increase the hotel profitability if are wisely operated and it is clear when more than $50 \%$ of respondents agree that The hotel's loyalty program offer reasonable cost. (Mean=3.74)

The highest mean is recorded with statement (I'd feel special if I was a member of hotel program loyalty) Mean= 3.84, with the same level the statement measuring the hotel program loyalty service benefits (I'd expect a better and quicker service as a loyalty member in Hotel program loyalty and I can choose from a variety of offers that suit me.) represent the highest mean (mean = 3.84). In this context, it can be said that that the measurement statements for frequent guests' program in hotels industry Are based on three factors namely (psychological treatment) (program benefits) and (reasonable cost). In addition we can observe that Program loyalty is above the average level. 
International Journal of Heritage, Tourism and Hospitality Vol. (11), No. (3/2)

Special issue on papers of the $10^{\text {th }}$ ICTH (2017) organized by Faculty of Tourism and Hotels, Fayoum University

Table 2: Results of frequent flyers' program in airlines industry

\begin{tabular}{|c|c|c|c|c|c|c|c|c|c|c|c|c|c|c|c|}
\hline \multirow[t]{2}{*}{ No } & \multirow[t]{2}{*}{ Loyalty Program(airline) } & \multicolumn{2}{|c|}{$\begin{array}{l}\text { Strongly } \\
\text { disagree }\end{array}$} & \multicolumn{2}{|c|}{ Disagree } & \multicolumn{2}{|c|}{ Neutral } & \multicolumn{2}{|c|}{ Agree } & \multicolumn{2}{|c|}{ Strongly agree } & \multirow[t]{2}{*}{ Mean } & \multirow[t]{2}{*}{ S.D } & \multirow[t]{2}{*}{ Attitude } & \multirow[t]{2}{*}{ Rank } \\
\hline & & No & $\%$ & No & $\%$ & No & $\%$ & No & $\%$ & No & $\%$ & & & & \\
\hline 1 & $\begin{array}{l}\text { I'd feel special if I was a member of airline } \\
\text { loyalty program. }\end{array}$ & 5 & 4 & .837 & 3.68 & 14.5 & 23 & 46.5 & 74 & 33.3 & 53 & 3.8 & 6 & 1.9 & 6 \\
\hline 2 & $\begin{array}{l}\text { I'd expect a better and quicker service as a } \\
\text { loyalty member in Airline program loyalty } \\
\text { and I can choose from a variety of offers that } \\
\text { suit me. }\end{array}$ & 1 & 4 & .852 & 3.79 & 19.5 & 31 & 46.5 & 74 & 28.3 & 45 & 4.4 & 7 & 1.3 & 2 \\
\hline 3 & $\begin{array}{l}\text { I purchase services presented by airline } \\
\text { because of benefits of frequent flyers } \\
\text { programs. }\end{array}$ & 3 & 4 & .840 & 3.75 & 18.2 & 29 & 45.3 & 72 & 31.4 & 50 & 3.8 & 6 & 1.3 & 2 \\
\hline 4 & $\begin{array}{l}\text { The airline's loyalty program treats members } \\
\text { better than non-members }\end{array}$ & 2 & 4 & .896 & 3.76 & 20.8 & 33 & 43.4 & 69 & 28.3 & 45 & 6.3 & 10 & 1.3 & 2 \\
\hline 5 & $\begin{array}{l}\text { The airline's loyalty program offer } \\
\text { reasonable cost. }\end{array}$ & 4 & 4 & .843 & 3.72 & 16.4 & 26 & 45.9 & 73 & 32.7 & 52 & 3.1 & 5 & 1.9 & 3 \\
\hline \multicolumn{12}{|c|}{ Overall frequent flyers' program } & .79124 & 3.7610 & \multicolumn{2}{|c|}{19.5} \\
\hline
\end{tabular}

Table 3: Results of flyers' satisfaction item

\begin{tabular}{|c|c|c|c|c|c|c|c|c|c|c|c|c|c|c|c|}
\hline \multirow[t]{2}{*}{ No } & \multirow[t]{2}{*}{ flyers' Satisfaction } & \multicolumn{2}{|c|}{$\begin{array}{l}\text { Strongly } \\
\text { disagree }\end{array}$} & \multicolumn{2}{|c|}{ Disagree } & \multicolumn{2}{|c|}{ Neutral } & \multicolumn{2}{|c|}{ Agree } & \multicolumn{2}{|c|}{$\begin{array}{l}\text { Strongly } \\
\text { agree }\end{array}$} & \multirow[t]{2}{*}{ Mean } & \multirow[t]{2}{*}{ S.D } & \multirow[t]{2}{*}{ Attitude } & \multirow[t]{2}{*}{ Rank } \\
\hline & & No & $\%$ & No & $\%$ & No & $\%$ & No & $\%$ & No & $\%$ & & & & \\
\hline 1 & I'm satisfied when I choose airline & 2 & 1.3 & 5 & 3.1 & 34 & 21.4 & 90 & 56.6 & 28 & 17.6 & 3.86 & .783 & 4 & 2 \\
\hline 2 & $\begin{array}{l}\text { My experience with Airline services } \\
\text { moderate my expectations }\end{array}$ & 2 & 1.3 & 6 & 3.8 & 44 & 27.7 & 86 & 54.1 & 21 & 13.2 & 3.74 & .781 & 4 & 4 \\
\hline 3 & I truly enjoyed staying at airline & 1 & .6 & 4 & 2.5 & 45 & 28.3 & 74 & 46.5 & 35 & 22.0 & 3.87 & .804 & 4 & 1 \\
\hline 4 & $\begin{array}{l}\text { Airline services were some of the best } 1 \\
\text { have ever received }\end{array}$ & 3 & 1.9 & 7 & 4.4 & 49 & 30.8 & 72 & 45.3 & 28 & 17.6 & 3.72 & .871 & 4 & 5 \\
\hline 5 & $\begin{array}{l}\text { I'm satisfied with airline in } \\
\text { comparison to others. }\end{array}$ & 3 & 1.9 & 5 & 3.1 & 41 & 25.8 & 81 & 50.9 & 29 & 18.2 & 3.81 & .838 & 4 & 3 \\
\hline & $\mathrm{Ov}$ & $\mathrm{eq}$ & II & $\mathrm{es}^{\prime} \mathrm{p}$ & grar & & & & & & & 3.8050 & .76703 & & \\
\hline
\end{tabular}

Source: The researcher based on Field Survey Data Analysis 
International Journal of Heritage, Tourism and Hospitality Vol. (11), No. (3/2)

Special issue on papers of the $10^{\text {th }}$ ICTH (2017) organized by Faculty of Tourism and Hotels, Fayoum University

Table 4: Results of flyers' loyalty items.

\begin{tabular}{|c|c|c|c|c|c|c|c|c|c|c|c|c|c|c|c|}
\hline \multirow[t]{2}{*}{ No } & \multirow[t]{2}{*}{ flyers' loyalty } & \multicolumn{2}{|c|}{$\begin{array}{l}\text { Strongly } \\
\text { disagree }\end{array}$} & \multicolumn{2}{|c|}{ Disagree } & \multicolumn{2}{|c|}{ Neutral } & \multicolumn{2}{|c|}{ Agree } & \multicolumn{2}{|c|}{ Strongly agree } & \multirow[t]{2}{*}{ Mean } & \multirow[t]{2}{*}{ S.D } & \multirow[t]{2}{*}{ Attitude } & \multirow[t]{2}{*}{ Rank } \\
\hline & & No & $\%$ & No & $\%$ & No & $\%$ & No & $\%$ & No & $\%$ & & & & \\
\hline 1 & I recommend Airline to others. & 4 & 2.5 & 6 & 3.8 & 42 & 26.4 & 81 & 50.9 & 26 & 16.4 & 3.75 & .864 & 4 & 1 \\
\hline 2 & I consider Airline to be my first choice. & 4 & 2.5 & 6 & 3.8 & 55 & 34.6 & 68 & 42.8 & 26 & 16.4 & 3.67 & .884 & 4 & 5 \\
\hline 3 & $\begin{array}{l}\text { I intend to fly at airline even though there are } \\
\text { other cheap offers. }\end{array}$ & 3 & 1.9 & 12 & 7.5 & 54 & 34.0 & 63 & 39.6 & 27 & 17 & 3.62 & .919 & 4 & 8 \\
\hline 4 & I say positive things about airline to others. & 4 & 2.5 & 4 & 2.5 & 52 & 32.7 & 78 & 49.1 & 21 & 13.2 & 3.68 & .829 & 4 & 4 \\
\hline 5 & $\begin{array}{l}\text { I always think of airline as an ideal airline } \\
\text { company }\end{array}$ & 5 & 3.1 & 3 & 1.9 & 48 & 30.2 & 77 & 48.4 & 26 & 16.4 & 3.73 & .869 & 4 & 2 \\
\hline 6 & $\begin{array}{l}\text { I consider myself a loyal customer of airline } \\
\text { and I will fly in airline in future }\end{array}$ & 4 & 2.5 & 7 & 4.4 & 55 & 34.6 & 70 & 44.0 & 23 & 14.5 & 3.64 & .875 & 4 & 6 \\
\hline 7 & $\begin{array}{l}\text { I provide the airline with my observations, my } \\
\text { ideas, and my proposals for the airline } \\
\text { improvement. }\end{array}$ & 3 & 1.9 & 7 & 4.4 & 58 & 36.5 & 69 & 43.4 & 22 & 13.8 & 3.63 & .846 & 4 & 7 \\
\hline 8 & $\begin{array}{l}\text { I defend the airline against other wrong } \\
\text { criticisms. }\end{array}$ & 5 & 3.1 & 4 & 2.5 & 56 & 35.2 & 65 & 40.9 & 29 & 18.2 & 3.69 & .908 & 4 & 3 \\
\hline & Overa & freq & at $\mathrm{fly}$ & $\mathrm{s}^{\prime} \mathrm{pr}$ & $a m$ & & & & & & & 3.6478 & 77450 & & \\
\hline
\end{tabular}

Source: The researcher based on Field Survey Data Analysis.

Table 5: Results of loyalty program in hotel items

\begin{tabular}{|c|c|c|c|c|c|c|c|c|c|c|c|c|c|c|c|}
\hline \multirow[t]{2}{*}{ No } & \multirow[t]{2}{*}{ Loyalty Program(Hotels) } & \multicolumn{2}{|c|}{$\begin{array}{l}\text { Strongly } \\
\text { disagree }\end{array}$} & \multicolumn{2}{|c|}{ Disagree } & \multicolumn{2}{|c|}{ Neutral } & \multicolumn{2}{|c|}{ Agree } & \multicolumn{2}{|c|}{ Strongly agree } & \multirow[t]{2}{*}{ Mean } & \multirow[t]{2}{*}{ S.D } & \multirow[t]{2}{*}{ Attitude } & \multirow[t]{2}{*}{ Rank } \\
\hline & & No & $\%$ & No & $\%$ & No & $\%$ & No & $\%$ & No & $\%$ & & & & \\
\hline 1 & $\begin{array}{l}\text { I'd feel special if I was a member of hotel } \\
\text { loyalty program. }\end{array}$ & 0 & 0 & 4 & 2.5 & 54 & 34.0 & 65 & 40.9 & 36 & 22.6 & 3.84 & .802 & Agree & 1 \\
\hline 2 & $\begin{array}{l}\text { I'd expect a better and quicker service as a } \\
\text { loyalty member in hotel program loyalty and I } \\
\text { can choose from a variety of offers that suit me. }\end{array}$ & 0 & 0 & 2 & 1.3 & 53 & 33.3 & 72 & 45.3 & 32 & 20.1 & 3.84 & .751 & Agree & 2 \\
\hline 3 & $\begin{array}{l}\text { I purchase services presented by hotel because } \\
\text { of benefits of frequent hotels programs. }\end{array}$ & 0 & 0 & 4 & 2.5 & 56 & 35.2 & 75 & 47.2 & 24 & 15.1 & 3.75 & .737 & Agree & 3 \\
\hline 4 & $\begin{array}{l}\text { The hotel's loyalty program treats members } \\
\text { better than non-members }\end{array}$ & 3 & 1.9 & 5 & 3.1 & 58 & 36.5 & 74 & 46.5 & 19 & 11.9 & 3.64 & .807 & Agree & 5 \\
\hline 5 & $\begin{array}{l}\text { The hotel's loyalty program offer reasonable } \\
\text { cost. }\end{array}$ & 1 & .6 & 3 & 1.9 & 53 & 33.3 & 81 & 50.9 & 21 & 13.2 & 3.74 & .731 & Agree & 4 \\
\hline & Overal & frequ & $\begin{array}{llll}\text { II } & \text { In }\end{array}$ & $s^{\prime} \mathrm{pr}$ & ram & & & & & & & 3.7925. & 64705 & & \\
\hline
\end{tabular}

Source: The researcher based on Field Survey Data Analysis

No. $=$ Number of respondents $\quad$ S.D $=$ Standard deviation 
International Journal of Heritage, Tourism and Hospitality Vol. (11), No. (3/2)

Special issue on papers of the $10^{\text {th }}$ ICTH (2017) organized by Faculty of Tourism and Hotels, Fayoum University

Table 6: Results of guest satisfaction items

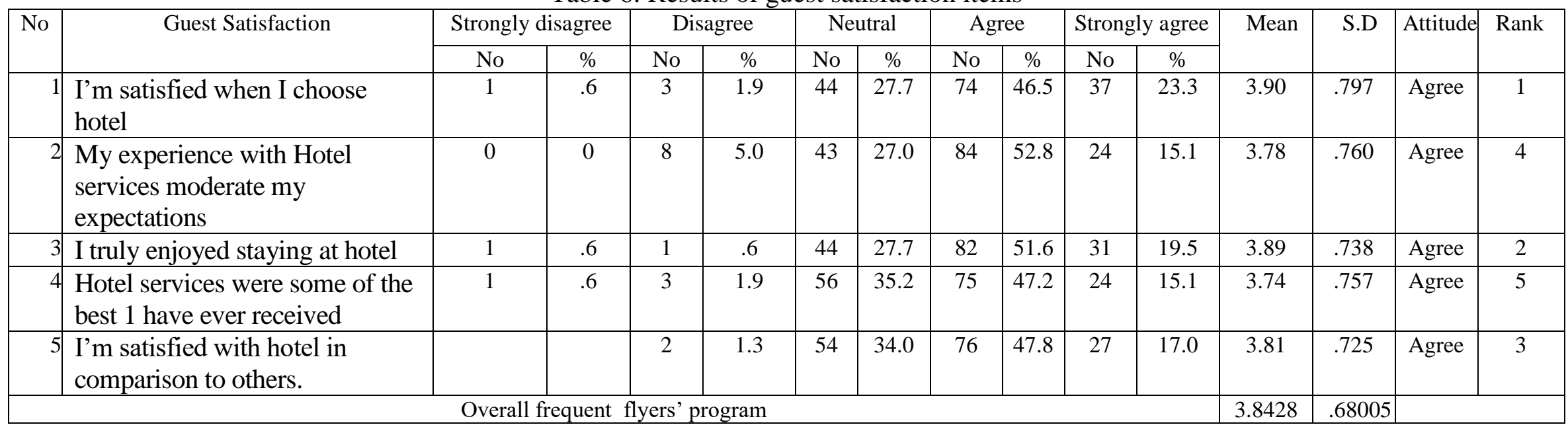

Source: The researcher based on Field Survey Data Analysis.

According to the Table (6) it is clear that guest satisfaction toward recommended hotel is above the average level.

The results actually indicate that most of respondents $(52.8 \%)$ agree that they are satisfied when they choose hotel with highest mean= 3.90 , and $51.65 \%$ agree to be enjoyed when staying at hotel with mean $=3.89$. To examine guest satisfaction among those surveyed, a review was made of the guest satisfaction scores with regards to the statements (Hotel services were some of the best 1 have ever received) mean $=3.74 . I$ 'm satisfied with hotel in comparison to others) mean $=3.81$ (Their experience with Hotel services moderate their expectations), with mean $=3.78$. Overall, the findings from Table (6) indicate the high level of guest satisfaction.

Table 7: Results of guest loyalty items

\begin{tabular}{|c|c|c|c|c|c|c|c|c|c|c|c|c|c|c|c|}
\hline \multirow[t]{2}{*}{ No } & \multirow[t]{2}{*}{ Guest Loyalty } & \multicolumn{2}{|c|}{$\begin{array}{l}\text { Strongly } \\
\text { disagree }\end{array}$} & \multicolumn{2}{|c|}{ Disagree } & \multicolumn{2}{|c|}{ Neutral } & \multicolumn{2}{|c|}{ Agree } & \multicolumn{2}{|c|}{ Strongly agree } & \multirow[t]{2}{*}{ Mean } & \multirow[t]{2}{*}{ S.D } & \multirow[t]{2}{*}{ Attitude } & \multirow[t]{2}{*}{ Rank } \\
\hline & & No & $\%$ & No & $\%$ & No & $\%$ & No & $\%$ & No & $\%$ & & & & \\
\hline 1 & I recommend hotel to others. & 1 & 6 & 4 & 2.5 & 50 & 31.4 & 81 & 50.9 & 23 & 14.5 & 3.76 & .750 & agree & 4 \\
\hline 2 & I consider hotel to be my first choice. & 2 & 1.3 & 4 & 2.5 & 55 & 34.6 & 63 & 39.6 & 35 & 22 & 3.79 & .860 & agree & 3 \\
\hline 3 & $\begin{array}{l}\text { I intend to stay at hotel even though } \\
\text { there are other cheap offers. }\end{array}$ & 1 & .6 & 19 & 11.9 & 44 & 27.7 & 65 & 40.9 & 30 & 18.9 & 3.65 & .941 & agree & 7 \\
\hline 4 & $\begin{array}{l}\text { I say positive things about hotel to } \\
\text { others. }\end{array}$ & 0 & 0 & 6 & 3.8 & 43 & 27 & 79 & 49.7 & 31 & 19.5 & 3.85 & .773 & agree & 2 \\
\hline 5 & $\begin{array}{l}\text { I always think of hotel as an ideal } \\
\text { accommodation }\end{array}$ & 0 & 0 & 4 & 2.5 & 46 & 28.9 & 77 & 48.4 & 32 & 20.1 & 3.86 & .759 & agree & 1 \\
\hline
\end{tabular}


International Journal of Heritage, Tourism and Hospitality Vol. (11), No. (3/2)

Special issue on papers of the $10^{\text {th }}$ ICTH (2017) organized by Faculty of Tourism and Hotels, Fayoum University

\begin{tabular}{|c|c|c|c|c|c|c|c|c|c|c|c|c|c|c|c|}
\hline 6 & $\begin{array}{l}\text { I consider myself a loyal customer of } \\
\text { hotel and I will stay in hotel in future }\end{array}$ & 0 & 0 & 10 & 6.3 & 51 & 32.1 & 71 & 44.7 & 27 & 17.0 & 3.72 & .818 & agree & 6 \\
\hline 7 & $\begin{array}{l}\text { I provide the hotel with my } \\
\text { observations, my ideas, and my } \\
\text { proposals for the hotel improvement. }\end{array}$ & 2 & 1.3 & 2 & 1.3 & 67 & 42.1 & 68 & 42.8 & 20 & 12.6 & 3.64 & .765 & agree & 8 \\
\hline 8 & $\begin{array}{l}\text { I defend the hotel against other wrong } \\
\text { criticisms. }\end{array}$ & 1 & .6 & 4 & 2.5 & 59 & 37.1 & 67 & 42.1 & 28 & 17.6 & 3.74 & .799 & agree & 5 \\
\hline
\end{tabular}

Source: The researcher based on Field Survey Data Analysis.

According to the table (7) results, it can be observed that guest's loyalty toward hotel is above the average level, about $50.9 \%$ agree to recommend Hotel to others and $49.7 \%$ of respondents agrees to say positive things about hotel to others. The highest mean is recorded with the statement (I always think of hotel as an ideal accommodation (mean $=3.86$ ) however, the lowest mean is recorded with the statement (I provide the hotel with my observations, my ideas, and my proposals for the hotel improvement.) mean $=3.64$. The overall results indicate the (agree level) in this context it can be said that the frequent loyalty program may have contributed to the increase in guests' loyalty.

Table 8: Correlation Matrix of Interrelationship among Study Variables of frequent guest/flyers program.

\begin{tabular}{|c|c|c|c|c|}
\hline \multicolumn{2}{|c|}{ variable } & Frequent loyalty & Guests satisfaction/ flyers' & Guest s loyalty/ Flyers \\
\hline \multirow{5}{*}{ 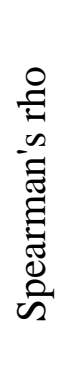 } & $\begin{array}{l}\text { Airlines loyalty program (loyalty } \\
\text { frequent flyers' programs) } \\
\text { Hotel loyalty program loyalty } \\
\text { frequent guests' programs) }\end{array}$ & 1.000 & & \\
\hline & Flyers satisfaction & $0.522 * *(0.000)$ & \multirow{2}{*}{1.000} & \\
\hline & Guest satisfaction & $0.355 * *(0.000)$ & & \\
\hline & Flyers loyalty & $0.683 * *(0.000)$ & $0.585 * *(0.000)$ & \multirow{2}{*}{1.000} \\
\hline & Guest loyalty & $0.558 * *(0.000)$ & $0.493 * *(0.000)$ & \\
\hline
\end{tabular}

The loyalty program (loyalty frequent guest/flyers programs) was significantly and positively correlated to guest/flyers satisfaction (p $<0.001$ ). The finding of the present study is in line with results of a study conducted by Zakaria et al. (2014), who explored the nature of the relationship between the hotel loyalty program and customer satisfaction. Therefore, hotel/airlines loyalty program is significant 
to enhance guest/flyers satisfaction, which consider as primary resource to create a positive behavior and commitment toward services providers. The finding of this study supported the critical role of hotel/airlines loyalty program as a better predictor for guest/flyers satisfaction in the hospitality/airlines industries because hotel/airlines loyalty program is capable of eliciting extraordinary levels of customers' motivation. It's noticeable that correlation p-value between frequent loyalty programs in airlines and guest satisfaction is more than frequent hotel loyalty programs.

The frequent loyalty programs (hotel/airlines loyalty program) were significantly and positively correlated to guests'/flyers' loyalty $(p<0.001)$. The finding of the present study is in line with results of a study conducted by Yoo (2011) who stated that hotel loyalty programs have a positive impact on customers' loyalty and hotel profitability. In the same line in the airlines industry Artuger and Calakoglu (2013) found that frequent loyalty programs have significant effect on customer loyalty. Therefore, hotel/airlines loyalty programs are significant to enhance guest/flyers loyalty, which consider as defense tools in hyperactive and competitive market, especially, if guest unsatisfied in his/her last experience (Anuar, 2013). The finding of this study supported the critical role of hotel loyalty program as a better predictor for guest loyalty in the hospitality industry because hotel loyalty program is vital marketing tools in attracting and maintain, and increase the guest behavior to repurchase hotel facilities, recommends the hotel to others, the loyal guest give positive word of mouth which is trust than marketing efforts, due to market growth and increase the hotel profitability. It worth to mention, that correlation p-value between frequent loyalty programs in airlines and guest loyalty is more than frequent hotel loyalty programs.

The satisfied guest was significantly and positively correlated to guest loyalty ( $\mathrm{p}<0.001)$. The finding of the present study is in line with results of a study conducted by Amin, Leila, and Zahra (2014), Zakaria et al. (2014). Therefore, customers' satisfaction is significant to enhance customers' loyalty, which considers as prerequisite to customers' loyalty, especially, if customers satisfied, he/she will encourage repurchasing, to referral the hotels' products and services to relatives. In the same vein on the airline, the Jay and kandompully (2016) noted that customer satisfaction is an important to expand the business, to expand their markets, results to profits. The finding of previous studies supported the critical role of guest/flyers satisfaction as a better predictor or precedent for guest loyalty in the hospitality industry (Suhartanto, 2000; Khan, 2012; Shrestha,2015; Choi 2015). Furthermore, the correlation p-value between flyers' satisfaction and flyers loyalty in airlines is more than guest satisfaction and guest loyalty in hotel industry.

Table 9: The effect of frequent loyalty programs on flyers'/guests' satisfaction

\begin{tabular}{|c|c|c|c|c|c|c|c|}
\hline \multicolumn{4}{|c|}{ Frequent flyers' programs } & \multicolumn{4}{|c|}{ Frequent guests' programs } \\
\hline \multicolumn{4}{|c|}{$\mathrm{R}^{2}=0.285$} & \multicolumn{4}{|c|}{$\mathrm{R}^{2}=0.122$} \\
\hline $\begin{array}{l}\text { Regression } \\
\text { Model }\end{array}$ & Beta & $\mathrm{t}$ & Sig. & $\begin{array}{l}\text { Regression } \\
\text { Model }\end{array}$ & Beta & $\mathrm{t}$ & Sig. \\
\hline Constant & 1.843 & 7.356 & .000 & Constant & 2.420 & 8.03 & .000 \\
\hline $\begin{array}{l}\text { Frequent flyers' } \\
\text { loyalty program }\end{array}$ & .522 & 7.998 & .000 & $\begin{array}{l}\text { Frequent guests } \\
\text { loyalty program }\end{array}$ & .375 & $\begin{array}{c}4.78 \\
7\end{array}$ & .000 \\
\hline
\end{tabular}

Dependent Variable: flyers' / guests' satisfaction

Independent variable: airlines' /hotel frequent loyalty programs

H1a: The result proved that the airlines loyalty programs (Frequent Flyers' Programs) was positively and significantly affects flyers' satisfaction $(\beta=.522, \mathrm{p}<0,01)$ and positively 
correlated (0.522). The determination coefficient recorded that $28.5 \%$ of the variability in the degree of flyers' satisfaction is explained by the degree of loyalty program. Thus, the H1a is accepted.

H1b: The result proved that the hotel loyalty programs (Frequent Guest' Programs) was positively and significantly affects guest' satisfaction $(\beta=.375, \mathrm{p}<0,01)$ and positively correlated $(0.355)$. The determination coefficient recorded that $12.2 \%$ of the variability in the degree of guests' satisfaction is explained by the degree of the loyalty programs (Frequent Guests' Programs). Then H1b is accepted.

These results are consistent with data obtained in previous studies (Keh and Lee 2006, Gomez, Arranz and Cillan, 2006; and Zakaria et al. 2014) who proved, the frequent loyalty program increased the motivation degree of the customers.

The most striking result to emerge from the data is that the airline loyalty programs was significant predictor on satisfaction and positively correlated than the hotel loyalty programs.

Table 10: The effect of frequent loyalty programs on flyers'/guests' loyalty

\begin{tabular}{|c|c|c|c|c|c|c|c|}
\hline \multicolumn{4}{|c|}{ Frequent Flyers' programs } & \multicolumn{4}{|c|}{ Frequent Guests' programs } \\
\hline & $=0.514$ & & & & $=0.2$ & & \\
\hline $\begin{array}{l}\text { Regression } \\
\text { Model }\end{array}$ & Beta & $\mathrm{t}$ & Sig. & $\begin{array}{l}\text { Regression } \\
\text { Model }\end{array}$ & Beta & $\mathrm{t}$ & Sig. \\
\hline Constant & 1.001 & 4.797 & .000 & Constant & 1.774 & 6.877 & .000 \\
\hline $\begin{array}{l}\text { Frequent flyers' } \\
\text { loyalty program }\end{array}$ & .704 & $\begin{array}{c}12.96 \\
2\end{array}$ & .000 & $\begin{array}{l}\text { Frequent guests } \\
\text { loyalty program }\end{array}$ & .525 & $\begin{array}{c}7.82 \\
8 \\
\end{array}$ & .000 \\
\hline
\end{tabular}

Dependent Variable: flyers' / guests' loyalty

Independent variable: airlines' /hotel frequent loyalty programs

H2a: The result proved that the airlines loyalty programs (Frequent Flyers' Programs) was positively and significantly affect flyers' loyalty $(\beta=0.704, p<0,01)$ and positively correlated (0.683). The determination coefficient recorded that $51.4 \%$ of the variability in the degree of perceived flyers' loyalty is explained by the degree of loyalty program (frequent Flyers' program). Thus, the H2a is accepted.

H2b: The result proved that the hotel loyalty programs (Frequent Guest' Programs) was positively and significantly affects guests' loyalty $(\beta=0.525, \mathrm{p}<0,01)$ and correlated $(0.558)$. The determination coefficient recorded that $27.6 \%$ of the variability in the degree of perceived guests' satisfaction is explained by the degree of the loyalty programs (Frequent Guests' Programs). Thus, the H2b is accepted.

The results showed the airline loyalty programs was significant variable on loyalty and positively correlated with it than the hotel loyalty programs.

These results are consistent with those of Yoo (2011), Artuger and Calakoglu (2013) who indicate that the frequent loyalty program may have contributed to the increase in flyers'/guests' loyalty.

Table 11: The effect of Flyers'/Guests satisfaction on flyers'/guests' loyalty

\begin{tabular}{|l|c|c|c|c|c|c|c|}
\hline \multicolumn{3}{|c|}{ Flyers' Satisfaction } & \multicolumn{5}{c|}{ Guests' Satisfaction } \\
\hline \multicolumn{3}{|c|}{$\mathrm{R}^{2}=0.434$} & \multicolumn{4}{c|}{$\mathrm{R}^{2}=0.278$} \\
\hline Regression Model & Beta & $\mathrm{t}$ & Sig. & Regression Model & Beta & $\mathrm{t}$ & Sig. \\
\hline Constant & 1.107 & 4.717 & 0.000 & Constant & 1.839 & 7.397 & .000 \\
\hline Flyers' satisfaction & .668 & 11.05 & .000 & $\begin{array}{c}\text { Guests' } \\
\text { satisfaction }\end{array}$ & .501 & 7.862 & .000 \\
\hline
\end{tabular}

Dependent Variable: flyers' / guests' loyalty Independent variable: flyers' / guests' satisfaction 
H3a: The result proved that the flyers' satisfaction positively and significantly affects flyers' loyalty $(\beta=0.668, p<0,01)$ and positively correlated $(0.585)$. The determination coefficient recorded that $43.4 \%$ of the variability degree of perceived flyers' loyalty is explained by the degree of flyers' satisfaction. Thus, the H3a is accepted.

H3b: The result proved that the guest satisfaction positively and significantly affects guests' loyalty $(\beta=0.501, p<0,01)$ and positively correlated $(0.493)$. the determination coefficient recorded that $27.8 \%$ of the variability in the degree of guests' loyalty is explained by the degree of guest satisfaction. Thus, the H3b is accepted.

The results confirm the findings of Jasinskas, et.al, (2016) who indicate that a positive significant link between customers' satisfaction and loyalty. Thus, satisfaction positively affects the intention of customers to purchase repeatedly, which mean the customer became loyal. The most striking result to emerge from the data is that the flyers' satisfaction on flyers' loyalty and positively correlated with it than the guests' satisfaction on guests' loyalty in hotel industry.

Table 12: The Mediation Coefficient of Relationship between Frequent Flyers'/guest Loyalty Programs and flyers'/guest loyalty

\begin{tabular}{|l|c|c|c|c|}
\hline \multicolumn{2}{|c|}{ Frequent Flyers' programs } & \multicolumn{2}{c|}{$\begin{array}{c}\text { Frequent Guests' } \\
\text { programs }\end{array}$} \\
\hline \multicolumn{1}{|c|}{ Path } & Coefficient & P-Value & Coefficient & P-Value \\
\hline The frequent loyalty program $\rightarrow$ Satisfaction & 0.522 & $* * *$ & 0.375 & $* * *$ \\
\hline The frequent loyalty program $\rightarrow$ Loyalty & 0.500 & $* * *$ & 0.386 & $* * *$ \\
\hline Satisfaction $\rightarrow$ Loyalty & 0.390 & $* * *$ & 0.370 & $* * *$ \\
\hline
\end{tabular}

H4a: The findings showed that the flyers' satisfaction mediates the relationship between frequent airline loyalty programs, and flyers' loyalty positively and significantly $\left(0.500^{* * *}\right)$. The authors can state that the flyers' satisfaction mediator variable had a significant, and total indirect effect between frequent airline loyalty programs, and flyers' loyalty. Specifically, frequent airline loyalty programs had a strong correlation with flyers' satisfaction $\left(0.522^{* * *}\right)$ that influenced in flyers' loyalty $\left(0.390^{* * *}\right)$. Therefore, the flyers' satisfaction played a vital mediating role in the relationships between frequent airline loyalty programs, and flyers' loyalty. Thus, the H4a is accepted.

H4b: The findings showed that the mediating effect of guests' satisfaction between frequent hotel loyalty programs, and guests' loyalty was positive and significant $\left(0.386^{* * *}\right)$. The authors can state that the guests' satisfaction mediator had a significant, and total indirect effect between frequent hotel loyalty programs, and guests' loyalty. Specifically, frequent hotel loyalty programs had a strong correlation with guests' satisfaction $\left(0.375^{* * *}\right)$ that influenced in flyers' loyalty $\left(0.370^{* * *}\right)$. Therefore, the guests' satisfaction played a vital mediating role in the relationships between frequent hotel loyalty programs, and guests' loyalty Thus, the H4b is accepted.

The findings proved that the mediating effect of satisfaction in airline industry was better than in hotel industry. Finally, the authors can state that flyers'/ guests' satisfaction as potential antecedents and perquisite in developing customer loyalty, which confirm the findings of Lam, Shanker, Erramilli, and Murthy (2004). Also, the authors stated that satisfaction is the first step toward the loyalty, but it's not enough to achieve the flyers'/ guests' loyalty. In the other word, the satisfied flyers/guests will recommend the service providers to friends, relatives, and others through positive word of mouth. Also, the satisfied flyers/guests defend the service provider against the bad criticisms. 
The following figure (3) summarizes the results obtained from the regressions, and mediation analysis of frequent flyers/guests loyalty programs.

Figure 3: Results obtained from the regressions and mediation analysis of frequent flyers/guests loyalty programs.

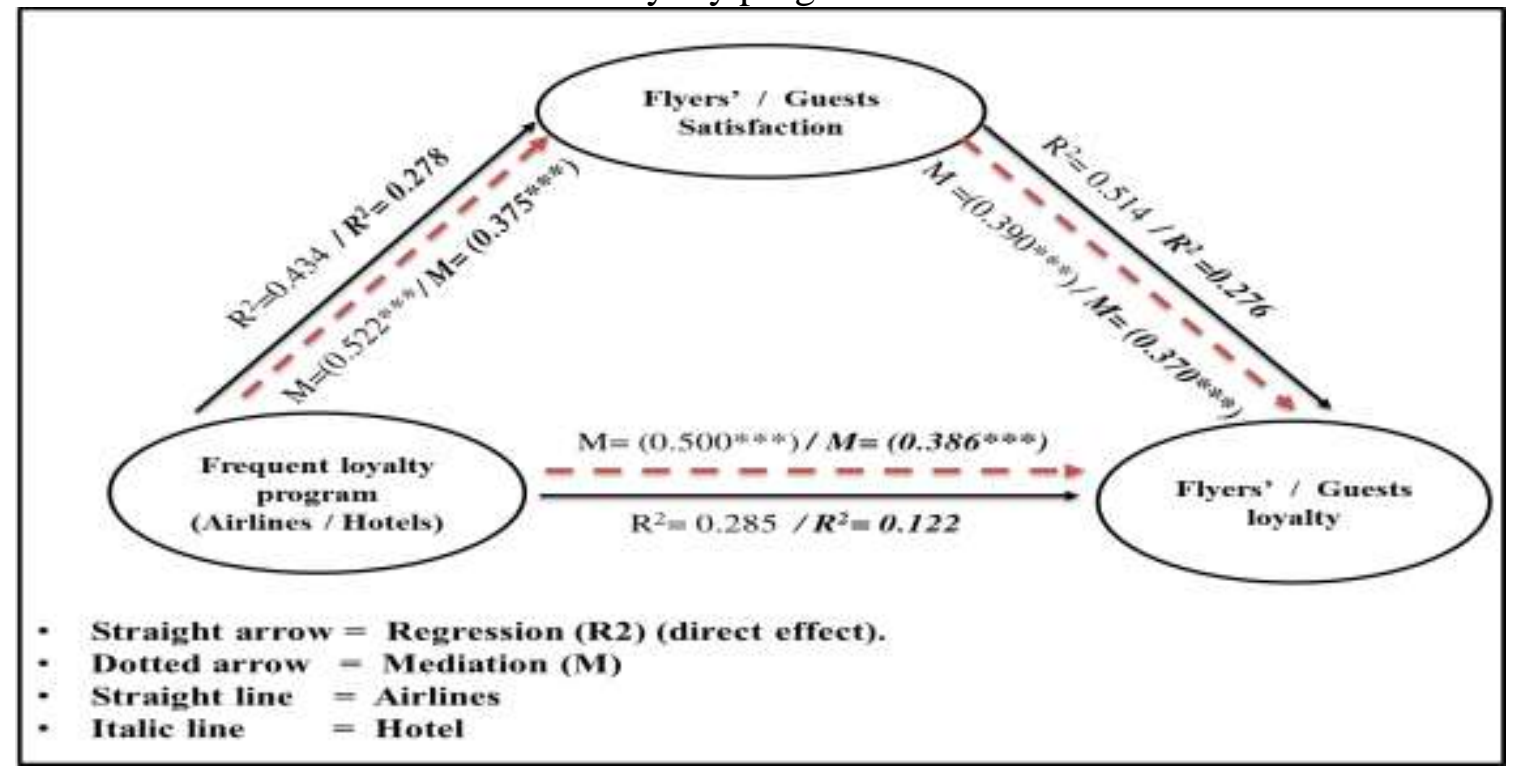

Source: The research Team.

\section{Limitations and Suggestions for Future Research}

Hence, it was difficult to use random sampling techniques because of the greatest number of participant. There for a convenience sample of different participants in loyalty program both in hotels and airlines together was the most suitable sampling techniques used in our research. Especially the airlines and hotels refused to give the research team any information about number of loyalty program members.

The number of empirical research in the hospitality industry which investigates the effect of loyalty programs on increasing customer loyalty is very limited. Hence, most of studies were applied in western countries (United States of America, Australia, New Zealand, Germany and the United Kingdom) where customers might exhibit different socio economic and cultural behavior responding loyalty program.

Due to the rejection of most hotels to personally administering the survey instrument, the administration of survey was limited to the assumption of responsibility by each coordinator at the participating properties. A detailed explanation of the questionnaires along with the instructions to carry out the survey as well as the contact information regarding the researcher was provided to each questionnaire and coordinator to control this limitation.

For future research our study found that most hotels loyalty programs in don't utilize loyalty program as effective as could be expected, so, future research could explore the reasons for the ineffectiveness of loyalty program in Alexandria and causal studies could be designed to fulfill this objective. Then a qualitative research could be used to investigate more about loyalty program membership and why flyers'/guests' become members of the loyalty program, and what is their experiences with the loyalty program, thus future research could focus on findings explanations for the reason of low number of customers' members in loyalty program. Further 
psychological study is recommended to ascertain the importance of loyalty program on customer choices and purchase decision.

Future research could explore the benefits gained from the application of loyalty programs in airlines and hotels industries.

Further research could study of loyalty hotel programs efficacy in various hospitality and tourism sector (restaurants, casino and travel agents).

A comparative study should be conducted between specific loyalty programs (ex: star plus program in Egypt air) in Hilton hotel (H Honors).

A research to study the relationship between the flyers'guests' loyalty program and employees' loyalty programs, and the impact of employees' loyalty programs to enhance the efficacy the customers' loyalty programs. Moreover, the impact of airlines loyalty program on long -haul flights and short-haul flights.

\section{Conclusions and Recommendations}

In summary, the findings of this study suggest that the frequent loyalty program increases the flyers'/guests satisfaction. Also, the findings from this study suggest that the frequent loyalty program can have an effect on flyers'/guests choice among service providers. The frequent loyalty program increases the satisfaction, enjoying with facilities and positive behavior towards the service provider if compared with competitors. Also, the most interesting finding with a comparative view was that the loyalty program increases the degree of flyers' satisfaction than guest satisfaction because the nature and components of airlines' frequent loyalty program. There are many likely causes for the differences between $\mathrm{p}$ - value of airlines and frequent hotel loyalty program were frequent airlines loyalty program have features such as the ease of redemption, strong appeal, and the partnership network that become more attractive than hospitality point award programs will influenced the degree of satisfaction (Dekay, Toh, and Raven 2009).

The second major finding was in line with those of previous studies (Lam, Shanker, Erramilli, and Murthy 2004) that the frequent loyalty program increases the flyers'/guests loyalty. If the competitors provide cheap offers, they still loyal and have positive behavior and positive wordof-mouth, and recommend the supplier to others, if the last experience unsatisfactory.

The flyers'/ guests' satisfaction mediated the relationship between the frequent loyalty programs and flyers'/ guests' loyalty is able to persuade flyers/guests to repeatedly purchase the services. On the other hand, they reveal that their loyalty to the service providers is not built up by loyalty programs as direct effects, but other factors as indirect effects for example satisfaction. These results would seem to suggest that the loyalty program have direct effects on satisfaction, and the satisfaction can lead to loyalty. Thus, the author can suggest the effective frequent loyalty program will motivate the flyers/guests to choose the airline/hotel facilities, built relationship with them. The flyers/guests will satisfy, and enjoy if they are receiving services and products meet their expectation or over, can lead to loyalty shown in recommending the hotel to others, and increasing the emotional attachment, making them more resistant if they were exposed to cheap offers, and defending the airline/hotel if anyone negatively criticizes.

The results also reveal that there are three factors which might affect the effectiveness of loyalty programs on building flyers'/guests loyalty particularly in the airlines and hospitality industries. The first factor is flyers'/guests involvement with the organization improvement by their comments, and ideas. Secondly, the cost saving, increase the flyers/guests motivation to participant in program. Thirdly, the benefits value gained from program participation. 


\section{Recommendations}

*Recommendations to improve the attractiveness of hotel loyalty programs to close the gap with airlines loyalty programs:

a- hotels should provide their loyalty program members with perfect exclusive service, that the airline cannot do (complimentary breakfast, disable facilities, aqua technology)

b- Because many frequent guest program members prefer airline miles to hotel points, Hotels should more aggressively partner with airline loyalty program so that hotel guests may have a choice between hotel points and airlines points.

*Recommendations to marketing managers:

a- Focus on some variables to enhance satisfaction and flyers/guests loyalty such as psychological benefits like personalized attention instead of tangible benefits to build personal relationship between $\mathrm{c}$ flyers/guests and the operations.

b- Expanding the evaluation framework in planning loyalty program to asses them continuously.

c- Psychological factors such as beliefs, trust, and perception, as well as rational factors such as value of money and risks certainly influence customer's decision-making. Hence, having an understanding that by offering merely financial incentives to attract customers and make them loyal toward the organizations might not be appropriate

d- It is important to understand which group is targeted in order to make loyalty program more significantly influence customer satisfaction and loyalty. Hence, managers should carefully design the most suitable benefits depending upon which group of customer's they target.

\section{References}

Amin, T.; Leila, R.N.; Zahra, F. (2014). Service quality, relationship quality and customer loyalty (Case study: Banking industry in Iran). Journal of Social Science. 2: 262 - 268.

Anuar, J., Sumarjan S., Radzi S.M. (2013). A preliminary study on the benefits of loyalty Programs in Malaysian city hotels. Journal of Tourism, Hospitality \& Culinary Arts. 5(2):198-214.

Baker, D.Mc.A., (2013). Service Quality and Customer Satisfaction in the Airline Industry: A Comparison between Legacy Airlines and Low-Cost Airlines, American Journal of Tourism Research 2(1):67-77.

Bartlett,J.E., Kotrlik,J.W,Higgins C.C., (2001) Determining Appropriate sample size in survey research, I nformation Technology, Learning and Performance Journal, Vol.19, No.1, Spring. PP.43-50.

Bishop. J. (2013). Customer Loyalty Programs: Are Rules Needed?, Public Interest Advocacy Centre 1204 -One Nicholas St Ottawa, Ontario.

Bolton, R., Kannan, P. K., \& Bramlett, M. (2000). Implications of loyalty program membership and service experiences for customer retention and value. Journal of the Academy of Marketing Science. 28(1), 95-108.

Bowen, T.J. \& Shoemaker, S. (2003). Loyalty, A Strategic Commitment. The Cornell Hotel and Restaurant Administration Quarterly. 44(5-6): 31-46.

Broekhuizen, I., \& Peelen, E. (1997). Het belonen van trouwe klanten. Tijdschrift voor Marketing, July-August, 52-56.

Brophy, K., (2006). Assessing the Efficacy of Guest Loyalty Programs in the Hotel Industry: A Case Study of Kimpton Hotels published master thesis, University of New Orleans. 
Buaphiban,T., (2015). Determination of Factors That Influence Passengers' Airline Selection: A Study of Low Cost Carriers in Thailand, published doctoral thesis, Embry-Riddle Aeronautical University Daytona Beach, Florida.

Butscher, A.S. (2002) Customer Clubs and Loyalty Programs. Abingdon, Oxon, GBR: Gower Publishing Limited.

Carev, D., (2008) Guest satisfaction and guest loyalty study for hotel Industry, Published master thesis. Rochester Institute of Technology at: http://scholarworks.rit.edu/theses.

Charania, N., (2011).Hospitality Loyalty Program Effectiveness Evaluation Rubric, published master thesis, University of Nevada, Las Vegas

Choi, E., (2015). The Influence of Tier Level of Hotel Loyalty Programs on Guest Perceptions and Tolerance for Service Quality, published master thesis, University of Nevada, Las Vegas.

Çolakoğlu O.E. (2013). The Effect of Frequent Flyer Programs on Customer Loyalty, The International Journal Of Social Science Vol.12.No.1. P 33-43.

Dowling GR., \& Uncles M., (1997). Do Customer Loyalty Programs Really Work? Sloan Management Review.38 (4).

Elebiary, A. M. H. (2012). Drivers of guest loyalty in the hotel industry in New Zealand: The role of staff loyalty, service quality, guest satisfaction and commitment, and the influence of loyalty programs. Published doctor thesis of philosophy in management. The University of Waikato.

Eunjin Choi, (2015). The Influence of Tier Level of Hotel Loyalty Programs on Guest Perceptions and Tolerance for Service Quality, Published master thesis, University of Nevada, Las Vegas.

Gil M.J.Á., Yan W. (2016) How Does Loyalty Program Affect Customer Satisfaction? The Case of Airlines and Hotels in Emerging Markets.

Gomez, B. G., Arranz, A. G., Cillian, J. G. (2006). The Role of Loyalty Programs in Behavioral and Affective Loyalty. Journal of Consumer Marketing, 387-396.

Grandpierre, L.G (2015).Customers' expectations and loyalty to their loyalty programs, how customers are reacting according to their socio-demographic factors, published Master thesis, Linnaeus University, Sweden.

Hantuli L. M. (2016). An Analysis of Hotel Loyalty Programs: A Case Study on the Hilton H Honors Loyalty Program. Published Theses in Hospitality Management. The Collins College of Hospitality Management. USA.

Hikkerova, L., (2014) . Loyalty programs: Acase study in the hospitality industry, International Journal Of Business, Vol .16,No.2, 150-164

Jasinskasa, E., Streimikieneb, D., Svagzdienea B., Simanaviciusa, A. (2016). Impact of hotel service quality on the loyalty of customers, Economic Research-Ekonomska Istraživanja. 29(1): 559572

Kandampully, J., Suhartanto,D., (2000),"Customer loyalty in the hotel industry: the role of customer satisfaction and image", International Journal of Contemporary Hospitality Management, Vol. 12 Iss 6 pp. $346-351$

Keh, H. T., Lee, Y. H. (2006). Do Reward Programs Build Loyalty for Services? The Moderating Effect of Satisfaction on Type and Timing or Rewards, Journal of Retailing, 82(2), 127-136

Lam, S. Y., Shankar, V., Erramilli, M. K., \& Murthy, B. (2004). Customer value, satisfaction, loyalty, and switching costs: An illustration from a business-tobusiness service context. Journal of the Academy of Marketing Science, 32(3), 293- 311.

Laškarin, M. (2013). Development of Loyalty Programs in the Hotel Industry. Tourism \& Hospitality Management, 19(1), 109-123. 
Lubbea, B., Douglasa, A., Mclachlana P. (2016), Airline loyalty of frequent Flyers: a survey of members and non-members of loyalty programs, African Journal of Hospitality, Tourism and Leisure.5(1)2223-814.

Meyer-Waarden, L. (2008). The influence of loyalty program membership on customer purchase behavior. European Journal of Marketing, 42(1/2), 87-114.

Mustafa T. (1999). 'Increasing brand loyalty in the hospitality Industry. International Journal of Contemporary Hospitality Management’. 11 (5): 223-229.

O’Brien, L., Jones, C. (1995). Do rewards really create loyalty? Harvard Business Review.73,75-82.

Oliver, R. L., Burke, R. (1999). Expectation processes in satisfaction formation: A field study. Journal of Service Research. 1, 196-214.

Ouhna, L., Mekkaoui, S. (2013). The Effect of Relationship Satisfaction in Customer Loyalty: Case Study of Moroccan Agri-Food Industries. International Journal of Business and Social Science, 4(11), 279-286.

Peter V. Raven (2009), Loyalty Programs: Airlines Outdo Hotels, Cornell Hospitality Quarterly, Volume 50, Issue ( 3) 371-382.

Petrick, J. F. (2004). Are loyal visitor's desired visitors? Tourism Management, 25(4), 463-470.

Pi, W. W., Huang, H. H. (2011). Effects of promotion on relationship quality and customer loyalty in the airline industry: The relationship marketing approach. African Journal of Business Management, 5(11), 4403-4414.

Shrestha B.R. (2014), Airline Brand Loyalty: A case study involving the three airlines, - SAS, Norwegian and Widerøe, Published master thesis, UIT the Arctic University of Norway.

Steinhoff. L., Palmatier R.W (2014). Understanding loyalty program effectiveness: managing target and bystander effects. Academy of marketing science.

Suhartanto, J.K. D (2000),"Customer Loyalty in The Hotel Industry: The Role Of Customer Satisfaction And Image", International Journal Of Contemporary Hospitality Management, 12(6) $346-351$.

Voorhees, C. Mccall, M (2010), THE drivers of loyalty program success: an organizing framework and research agenda, Cornell university. 51(1): 35-52.

Wansink, B. (2003), Developing a cost-effective brand loyalty program. Journal of Advertising Research, 43(3), 301-309.

Wathigo, P. (2016). The effect of loyalty program s on customer patronage of supermarkets in Nairobi County, Published master thesis Strathmore university, Kenya.

Wijaya S. (2005) The Effect of Loyalty Programs On Customer Loyalty In The Hospitality Industry, Jurusan Manajemen Perhotelan, Fakultas Ekonomi - Universitas Kristen Petra 2431. JURNAL MANAJEMEN PERHOTELAN, VOL. 1, NO. 1, MARET : 24-31

Yan W., Cui, Z. (2016). Factors Contributing to Popularity of Loyalty Programs: Evidence From Emerging Markets. Cornell Hospitality Quarterly. 10.1177/193

Yoo, M. (2011). The long-term impact of a loyalty program: An evaluation from a las vegas casino hotel. Published Doctoral dissertation William F. Harrah College of Hotel Administration. The Graduate College University of Nevada, Las Vegas. USA.

Zakaria, I., Ab.Rahman, B., Othman, a.k., Yunus, N. A. M., Dzulkipli M. R., Osman. A.F. (2014), The Relationship between Loyalty Program, Customer Satisfaction and Customer Loyalty in Retail Industry: A Case Study Center for Applied Management Studies, Faculty of Business Management, University Teknologi MARA (UiTM), Malaysia Procedia - Social and Behavioral Sciences $12923-30$. 